South Dakota State University

Open PRAIRIE: Open Public Research Access Institutional Repository and Information Exchange

Agronomy, Horticulture and Plant Science Faculty Department of Agronomy, Horticulture, and Plant

Publications

Science

2006

Influence of Yellow Foxtail on Corn Growth and Yield

S. A. Clay

K. R. Banken

F. Forcella

M. M. Ellsbury

D. E. Clay

See next page for additional authors

Follow this and additional works at: https://openprairie.sdstate.edu/plant_faculty_pubs 
Authors

S. A. Clay, K. R. Banken, F. Forcella, M. M. Ellsbury, D. E. Clay, and A. E. Olness 


\title{
Influence of Yellow Foxtail on Corn Growth and Yield
}

\author{
S. A. Clay , K. R. Banken , F. Forcella , M. M. Ellsbury , D. E. Clay \& A. E. Olness
}

To cite this article: S. A. Clay , K. R. Banken , F. Forcella , M. M. Ellsbury , D. E. Clay \& A. E. Olness (2006) Influence of Yellow Foxtail on Corn Growth and Yield, Communications in Soil Science and Plant Analysis, 37:9-10, 1421-1435, DOI: 10.1080/00103620600628813

To link to this article: https://doi.org/10.1080/00103620600628813

曲 Published online: 15 Aug 2006.

Submit your article to this journal $\pi$

Џ Article views: 41

Citing articles: 4 View citing articles $ک \pi$ 
Communications in Soil Science and Plant Analysis, 37: 1421-1435, 2006

Copyright (C) Taylor \& Francis Group, LLC

ISSN 0010-3624 print/1532-2416 online

DOI: $10.1080 / 00103620600628813$

\title{
Influence of Yellow Foxtail on Corn Growth and Yield
}

\author{
S. A. Clay and K. R. Banken \\ Plant Science Department, South Dakota State University, Brookings, \\ South Dakota, USA

\section{F. Forcella} \\ United States Department of Agriculture-Agricultural Research \\ Service, Morris, Minnesota, USA

\section{M. Ellsbury} \\ United States Department of Agriculture-Agricultural Research \\ Service, Northern Grain Insect Research Laboratory, Brookings, \\ South Dakota, USA

\section{E. Clay} \\ Plant Science Department, South Dakota State University, Brookings, \\ South Dakota, USA

\section{A. E. Olness} \\ United States Department of Agriculture-Agricultural Research \\ Service, Morris, Minnesota, USA
}

\begin{abstract}
Yellow foxtail [Setaria pumila syn. Setaria glauca (L.) Beauv.] competitive influence on corn (Zea mays L.) growth and yield was investigated at Brookings, South Dakota, and Morris, Minnesota, in 1995 and 1996. Yellow foxtail was seeded at different densities, and at Morris, two levels of nitrogen $(\mathrm{N})$ were applied. Corn biomass measured at V-6 or V-8, silking, and harvest and grain yield were correlated negatively to foxtail biomass and density, but the loss differed between years and sites. Nitrogen increased corn growth and decreased yield loss. Defining a single foxtail density or biomass that resulted in a maximum yield loss of $10 \%$ was not possible.
\end{abstract}

Received 18 April 2005, Accepted 16 September 2005

Address correspondence to S. A. Clay, Plant Science Department, South Dakota State University, Brookings, SD 57007, USA. E-mail: sharon.clay@sdstate.edu 
The most conservative estimate was 3 yellow foxtail plants $\mathrm{m}^{-2}$ or $24 \mathrm{~g} \mathrm{~m}^{-2}$ of yellow foxtail biomass, but ranged up to 55 plants $\mathrm{m}^{-2}$ and $256 \mathrm{~g} \mathrm{~m}^{-2}$ when weather conditions and $\mathrm{N}$ were optimal.

Keywords: Competition, interference, yield loss

\section{INTRODUCTION}

Yellow foxtail [S. pumila syn. S. glauca (L.) Beav.], green foxtail [S. viridis (L.) Beauv.], and giant foxtail (S. faberii Herrm.) are the most commonly found foxtail species in the midwestern region of the United States (Rominger 1962). Yellow foxtail is and has been problematic (Nieto and Staniforth 1961; Bridges 1992) for several reasons. A single yellow foxtail plant may produce 6,500 seeds that can remain viable in soil for up to 15 years (Stevens 1932; Darlington 1951; Dawson and Bruns 1975). Yellow foxtail growth is elastic with upright forms (up to $110 \mathrm{~cm}$ tall) in corn and prostrate forms (less than $50 \mathrm{~cm}$ tall) in alfalfa (Medicago sativa L.) if multiple cuttings are taken (Schoner, Norris, and Chilcote 1978). The life cycle of yellow foxtail can be completed in less than 30 days from germination to seed set in some conditions, and seeds can germinate throughout the summer if soil moisture is favorable (Clay and Scholes 1992; Forcella et al. 1997).

Herbicidal control of yellow foxtail also can be problematic. Multiple germination events complicate control timing, especially with nonresidual methods, and escapes can compete with the crop throughout the rest of the season. Wang and Dekker (1995) reported that yellow foxtail has tolerance to metolachlor and some tolerance to atrazine. Older plants are generally more tolerant to both herbicides because of an increased ability to detoxify these herbicides compared to seedling plants (Hatton, Cole, and Edwards 1996).

Yellow foxtail has been reported to reduce corn yield up to $80 \%$, although the amount of crop yield reduction varies widely among sites, years, and yellow foxtail densities (Lindquist et al., 1999). Cultural management of corn, such as row spacing (Forcella, Westgate, and Warnes 1992; Anderson 2000) and N application (Nieto and Staniforth 1961; Tollenaar et al. 1992), influences yield loss due to weeds. The objectives of this study were to determine corn growth and yield reduction due to different yellow foxtail densities at two sites (Brookings, South Dakota, and Morris, Minnesota) in 2 years.

\section{MATERIALS AND METHODS}

\section{Field Experiments}

This study was conducted in 1995 and 1996. The soil at Morris, Minnesota $\left(45^{\circ} 35^{\prime} \mathrm{N}, \quad 95^{\circ} 55^{\prime} \mathrm{W}, 344 \mathrm{~m}\right.$ altitude) was an Aastad clay loam 
(Pachic Hapludoll) with sand, silt, and clay contents of 270, 470, and $260 \mathrm{~g} \mathrm{~kg}^{-1}$, respectively. The soils at the Brookings, South Dakota $\left(44^{\circ} 19^{\prime} \mathrm{N}, 96^{\circ} 46 \mathrm{~W}, 500 \mathrm{~m}\right.$ altitude) were both Calcic Hapludolls. In 1995 , the soil was a Barnes clay loam with sand, silt, and clay contents of 450, 340 , and $222 \mathrm{~g} \mathrm{~kg}^{-1}$, respectively. The soil in 1996 was a Vienna silty clay loam with sand, silt, and clay contents of 180,520 , and $340 \mathrm{~g} \mathrm{~kg}^{-1}$, respectively. Monthly precipitation and growing degree days (GDD) (base $10^{\circ} \mathrm{C}$ ) for each year and site are presented in Table 1 . Soybean was the preceding crop at all locations.

Nitrate- $\mathrm{N}$ in the 0 - to $30-\mathrm{cm}$ depth of each plot was determined by extracting $10 \mathrm{~g}$ of a six-soil core composite air-dried sample with $100 \mathrm{~mL}$ of $1-\mathrm{M} \mathrm{KCl}$ and measuring $\mathrm{N}$ concentration of the extract using a Wescan Ammonia Analyzer (Mulvaney 1996). Soil N levels at Morris were low $\left(28 \mathrm{~kg} \mathrm{~N} \mathrm{ha}^{-1}\right.$ ) and allowed high and low $\mathrm{N}$ treatments to be established. A surface $15-\mathrm{cm}$ - wide band of dry starter fertilizer $\left(28-28-28 \mathrm{~kg} \mathrm{ha}^{-1}\right.$ equivalent $\mathrm{N}-\mathrm{P}-\mathrm{K}$ ) was applied at planting over all plots in both years. The high $\mathrm{N}$ treatment received a second application of urea (46-0-0) that was broadcast at $110 \mathrm{~kg} \mathrm{~N} \mathrm{ha}^{-1}$ at the $\mathrm{V}-8$ stage of corn growth in 1995 and at planting in 1996. Soil $\mathrm{N}$ levels at Brookings were high $\left(100 \mathrm{~kg} \mathrm{~N}^{-1}\right)$ in 1995 , and no additional fertilizer was applied. In 1996, urea at a $110-\mathrm{kg} \mathrm{N}^{-1}$ rate was applied broadcast at planting. The yield goals in the high $\mathrm{N}$ treatment (Morris) and at Brookings were 7,500 $\mathrm{kg} \mathrm{ha}^{-1}$.

Two passes of a field cultivator were done each spring for seedbed preparation. Corn variety Pioneer 3893 with a 90-day maturity rating was planted on May 17, 1995, and May 13, 1996, at Morris. At Brookings, Pioneer 3769 with a 97-day maturity rating was planted on May 24, 1995, and May 15, 1996. Seed density for all plantings was 69,000 seeds $^{-1}$ with a row spacing of $76 \mathrm{~cm}$.

Yellow foxtail seed was band applied immediately after corn planting using a modified push-type garden fertilizer spreader to form a 30-cm-wide band that was centered over the corn row. A lawn rake was used to cover the seed with about 2-cm of soil. Foxtail seed germination in the laboratory was $25 \%$ based on 10-day tests. Seeding rates in the field were (0) (weedfree), 450, 1,100, 2,200, and 4,200 seeds $/ \mathrm{m}^{2}$ with desired final densities of $0,110,275,550$, and 1075 plants $/ \mathrm{m}^{2}$. These densities were chosen to provide a range of yield loss. Foxtail plants were thinned by hand at about 10 (foxtail emergence), 20, and 30 days after planting (DAP).

Broadleaf weeds were controlled at all sites by a broadcast application of dicamba (diglycolamine salt) at $0.5 \mathrm{~kg}$ ae ha ${ }^{-1}$ on June 15,1995 , and June 12, 1996, at Morris and on June 20, 1995, and June 13, 1996, at Brookings. Nicosulfuron was applied to control grass weeds in weed-free plots on these same dates at a rate of $35 \mathrm{~g}$ ai ha ${ }^{-1}$. Herbicides were applied at $94 \mathrm{~L}_{\text {water ha }}{ }^{-1}$ at $276 \mathrm{kPa}$ with a push-type bicycle sprayer. Plots were cultivated 7 to 10 days after herbicide application both years to remove interrow weeds and left only the $30-\mathrm{cm}$ yellow foxtail band. 
Table 1. Monthly precipitation and growing degree days (base $10^{\circ} \mathrm{C}$ ) summaries for 1995 and 1996 and 30-yr averages for these parameters for Morris, MN, and Brookings, SD

\begin{tabular}{|c|c|c|c|c|c|c|c|}
\hline \multirow[b]{2}{*}{ Location } & \multirow[b]{2}{*}{ Month } & \multicolumn{3}{|c|}{ Precipitation $(\mathrm{cm})$} & \multicolumn{3}{|c|}{$\mathrm{GDD}^{a}$} \\
\hline & & 30 -yr average ${ }^{b}$ & 1995 & 1996 & 30 -yr average ${ }^{b}$ & 1995 & 1996 \\
\hline \multirow[t]{6}{*}{ Morris, MN } & May & 7.0 & 7.8 & 8.3 & 168 & 129 & 134 \\
\hline & June & 9.4 & 5.3 & 6.0 & 267 & 335 & 303 \\
\hline & July & 8.5 & 17.1 & 8.4 & 348 & 337 & 304 \\
\hline & August & 8.2 & 15.9 & 4.7 & 310 & 367 & 294 \\
\hline & September & 6.0 & 6.8 & 6.2 & 176 & 196 & 169 \\
\hline & Total & 39.1 & 52.9 & 33.6 & 1269 & 1364 & 1204 \\
\hline \multirow[t]{6}{*}{ Brookings, SD } & May & 7.4 & 11.4 & 12.5 & 168 & 104 & 137 \\
\hline & June & 11.0 & 6.9 & 7.2 & 266 & 282 & 307 \\
\hline & July & 8.4 & 17.3 & 2.1 & 344 & 334 & 334 \\
\hline & August & 7.1 & 11.3 & 7.6 & 310 & 364 & 365 \\
\hline & September & 6.7 & 9.9 & 6.6 & 187 & 181 & 211 \\
\hline & Total & 40.8 & 57.1 & 36.2 & 1275 & 1265 & 1354 \\
\hline
\end{tabular}

${ }^{a}$ Growing degree days (GDD) (base $10^{\circ} \mathrm{C}$ ) calculated by [(day's high temperature + day's low temperature) $/ 2$ ] -10 The maximum high temperature used in the equation is $30^{\circ} \mathrm{C}$ and the minimum low temperature is $10^{\circ} \mathrm{C}$.

${ }^{b} 30$-year average was calculated using data from 1964-1994. 


\section{Plant Samples}

Corn height, leaf stage, and leaf chlorophyll content (using a chlorophyll meter, SPAD 502, Minolta Co.) were measured on five corn plants per plot during late June (V-8 stage of growth at Morris in 1995, V-6 stage at all other times) and early August (silking). Yellow foxtail plant and stem densities were counted in four $0.1-\mathrm{m}^{2}$ areas of the grass band per plot at each sampling. Corn and yellow foxtail plants in the measured areas were harvested, dried at $60^{\circ} \mathrm{C}$ to constant weight, and weighed to determine biomass.

At physiological maturity (black layer formation), corn ears were hand harvested along two 5-m rows (at Morris, in 1995) or 8-m rows (all other plots) from undisturbed areas in the center of the plots. Grain yield was determined after drying and shelling with correction to $15.5 \%$ water content. Corn stover within the harvest areas and yellow foxtail within a $2-\mathrm{m}$ by $30-\mathrm{cm}$ band in the harvest area was cut at the soil surface, and biomass was determined as previously described. Plant material from each sampling date was ground finely, and a 3-mg sample was used for total $\mathrm{N}$ analysis using an N/C Analysis Mass Isotope Spectrophotometer (Europa Scientific, Inc.) (Barrie et al. 1995).

\section{Statistical Analyses}

The experimental design was a randomized complete block (RCB) with four replications for each experimental treatment. Plots were $3 \mathrm{~m}$ wide (4 corn rows with $76-\mathrm{cm}$ row spacing) and $15 \mathrm{~m}$ long. Treatments in this experiment were intended to be five levels of foxtail density and, at Morris, two levels of $\mathrm{N}$ application. However, because of the wide variation in yellow foxtail densities, even within a desired density, the data were continuous rather than discrete, and regression with correlation was used at a significance level of $P \leq 0.05$ to investigate relationships among measured parameters within a sampling date (SAS 1989). Correlation analysis assumes a linear relationship between variables, which, of course, often is not realistic. Consequently, correlation analysis simply explored trends in relationships for a variety of measured variables.

Yield data also were analyzed using the hypberbolic model

$$
Y=\frac{I_{d} \times D}{1+I_{d} \times D / A_{d}}
$$

where $Y$ is corn yield loss, $D$ is foxtail density, $A_{d}$ represents the maximum percentage of yield loss at high densities, and $I_{d}$ represents the yield loss percentage per weed (Cousens 1985). General results for the yield data have been reported previously (Lindquist et al. 1999). 
This formula was also used to explore the hyperbolic model to describe yield loss as a function of yellow foxtail biomass at harvest. $D$ was replaced with $B$ to represent yellow foxtail biomass at harvest, and $A_{b}$ and $I_{b}$ represented the maximum yield loss at high biomass and yield loss percentage per $\mathrm{g}$ foxtail biomass $\mathrm{m}^{-2}$, respectively. The foxtail biomass that caused $10 \%$ yield loss also was determined.

\section{RESULTS AND DISCUSSION}

\section{Morris}

The 1995 growing season was warm and wet, whereas 1996 was cool and dry (Table 1). Season-long total precipitation during 1995 and 1996 was 35\% above and $14 \%$ below the 30-year average (1965-1994) of $39.1 \mathrm{~cm}$, respectively. June 1995, during corn vegetative development, was dry, with precipitation $44 \%$ below normal. However, rainfall amounts in July (corn at V6-tassel growth stages) and August (corn at R1-R4 growth stages) of 1995 were double the 30-year average. In 1996, rainfall amounts in June and August were 36 and $42 \%$ below the 30 -year average, respectively.

GDD (base $10^{\circ} \mathrm{C}$ ) were $7 \%$ above and $5 \%$ below the 30 -year average of 1270 in 1995 and 1996, respectively (Table 1). The total GDD of June, August, and September were 25, 18, and $11 \%$ above normal, respectively. In 1996, GDD accumulations were above normal in June (13\%) but below normal in May $(-20 \%)$, July $(-13 \%)$, August $(-5 \%)$ and September $(-4 \%)$. Daily weather variables, including minimum and maximum air temperatures and rainfall, were used in WeedCast2 (Archer, Eklund, and Forcella 2000) to simulate foxtail germination. At 15 DAP, the proportion of yellow foxtail emerged was estimated to be $6.3 \%$ of the total emerged in 1995 and $11.2 \%$ of the total emerged in 1996.

In 1995, plant density and biomass of yellow foxtail were correlated positively at all sampling dates (Table 2) and averaged about three tillers per plant at the V-8 and silking stages of corn growth (data not shown). Foxtail biomass at V-8, silking, and physiological maturity stages of corn growth averaged about 150,290 , and $650 \mathrm{~g} \mathrm{~m}^{-2}$, respectively, and was equal to or greater than corn biomass at vegetative and silking sampling times (data not shown). Individual foxtail plant weights at silking ranged from about $0.12 \mathrm{~g}$ at high densities to about $3.8 \mathrm{~g}$ at lower densities.

Corn data, except yield, were averaged over $\mathrm{N}$ treatments in 1995. Corn biomass was not correlated with foxtail density or biomass at V-8 sampling but was negatively correlated with these parameters at silking and harvest (Table 2 and Figure 1). At harvest, the $\mathrm{N}$ treatment increased grain yield in the weed-free treatment from about 9,200 to $11,800 \mathrm{~kg} \mathrm{ha}^{-1}$ but did not influence stover biomass. Nitrogen also alleviated yield loss when yellow foxtail did not exceed 400 plants $\mathrm{m}^{-2}$ (Lindquist et al. 1999). Maximum 
Table 2. Correlation coefficients $(r)$ of measured yellow foxtail and corn parameters in 1995 at the Morris, MN location, at V-8, silking, and physiological maturity of corn growth

\begin{tabular}{llccr}
\hline & \multicolumn{1}{c}{$\begin{array}{c}\text { Parameter } \\
\text { measured }\end{array}$} & $\begin{array}{c}\text { Foxtail } \\
\text { biomass }\end{array}$ & Biomass & Yield \\
\cline { 4 - 5 } V-8 & $\begin{array}{l}\text { Foxtail density } \\
\text { Foxtail biomass }\end{array}$ & 0.78 & $\mathrm{NS}^{a}$ & - \\
& $\begin{array}{l}\text { Corn biomass } \\
\text { Silking }\end{array}$ & & $\mathrm{NS}$ & - \\
& Foxtail density & 0.78 & -0.44 & - \\
& Foxtail biomass & & -0.39 & - \\
Physiological & Corn biomass & & & -0.48 \\
maturity & Foxtail density & 0.58 & -0.53 & -0.52 \\
& Foxtail biomass & & -0.52 & -0.88 \\
\hline
\end{tabular}

Note: Data were combined over N levels because correlation coefficients were similar.

${ }^{a} \mathrm{NS}$ indicates correlation between parameters is $p>0.05$. All other values are significant at $p \leq 0.05$.

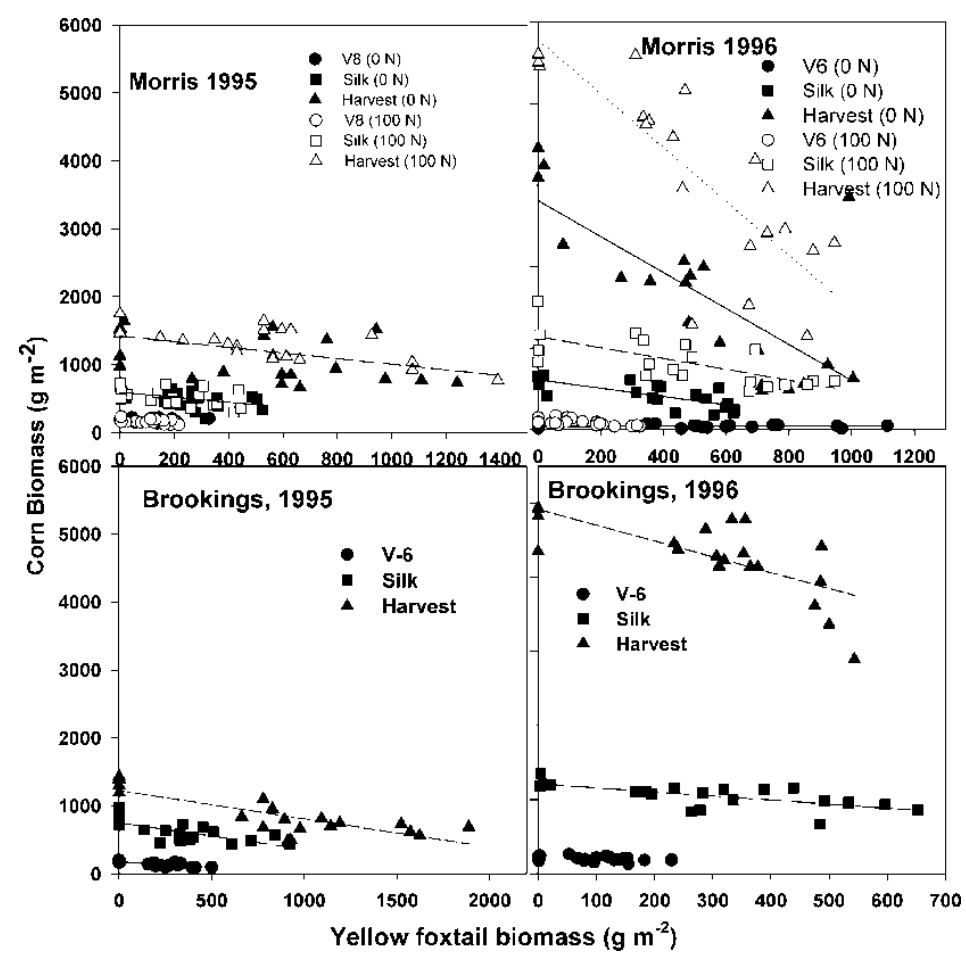

Figure 1. Corn biomass at a vegetative stage, silking, and harvest as influenced by yellow foxtail biomass for Morris and Brookings in 1995 and 1996. Correlation coefficients for the linear regressions are presented in Tables 2-4. 
yield loss $\left(A_{b}\right)$ based on yellow foxtail biomass was estimated at $46 \%$ for low $\mathrm{N}$ treatment and $42 \%$ for the high $\mathrm{N}$ treatment (Table 3 and Figure 2). Ten percent yield loss was estimated to occur when foxtail biomass reached 24 and $195 \mathrm{~g} \mathrm{~m}^{-2}$ in the low and high $\mathrm{N}$ treatments, respectively.

In 1996, $\mathrm{N}$ application increased foxtail biomass only at V-6, from an average of $120 \mathrm{~g} \mathrm{~m}^{-2}$ to $162 \mathrm{~g} \mathrm{~m}^{-2}$ in the low and high $\mathrm{N}$ treatments, respectively. As in 1995, foxtail density and biomass were correlated positively at all sampling dates (Table 4). Low foxtail densities tended to have a greater number of tillers per plant than treatments with high numbers of foxtail plants (data not shown), and because of this total numbers of foxtail stems were similar across all densities (Banken 2000).

Corn biomass was correlated negatively with both foxtail density and biomass at most sampling times (Table 4 and Figure 1). Yield was correlated negatively with foxtail density and foxtail biomass. In 1996, yields ranged from $4,100 \mathrm{~kg} / \mathrm{ha}$ (highest foxtail density and low $\mathrm{N}$ ) to $11,800 \mathrm{~kg} / \mathrm{ha}$ (weed-free and high $\mathrm{N}$ ). Nitrogen application reduced the incremental yield loss $\left(I_{b}\right)$ based on foxtail biomass from $0.41 \%$ per $g$ foxtail $\mathrm{m}^{-2}$ (low $\mathrm{N}$ ) to $0.18 \%$ (high $\mathrm{N}$ ) (Figure 2 and Table 3). Ten percent yield loss was estimated when foxtail biomass was 27 and $65 \mathrm{~g} \mathrm{~m}^{-2}$ in the low and high $\mathrm{N}$ treatments, respectively.

\section{Brookings}

The 1995 growing season in Brookings was wet with average temperatures, whereas 1996 was dry and slightly warmer than normal (Table 1). In 1995 total rainfall was higher than the 30 -year average with above average amounts for all months but June, which was $37 \%$ below normal. In contrast, precipitation in 1996 was $11 \%$ below normal for the growing season. Rainfall in May was $68 \%$ above normal and below normal in June $(-35 \%)$ and July $(-74 \%)$. GDD totals were normal in 1995 and 6\% above the 30-year average in 1996.

Table 3. Equation parameters for the hyperbolic model $Y=I_{b} \times \mathrm{B} /\left(1+I_{b} \times B / A_{b}\right)$, which relates corn yield reduction $(\%)$ with yellow foxtail biomass $\left(\mathrm{g} \mathrm{m}^{-2}\right)$, where $I_{b}$ represents the incremental yield loss percentage per $g$ of biomass and $A$ represents the maximum yield loss percentage

\begin{tabular}{llcccc}
\hline Year & Location & N rate $\left(\mathrm{kg} \mathrm{ha}^{-1}\right)$ & $\mathrm{I}(\%)$ & $\mathrm{A}(\%)$ & Adj. $R^{2}$ \\
\hline 1995 & Morris & 0 & 0.56 & 46 & 0.31 \\
& & 100 & 0.06 & 42 & 0.42 \\
\multirow{2}{*}{1996} & Brookings & & 0.11 & 57 & 0.61 \\
& Morris & 0 & 0.41 & 75 & 0.51 \\
& & 100 & 0.18 & 75 & 0.45 \\
& Brookings & & NS & 30 & \\
\hline
\end{tabular}



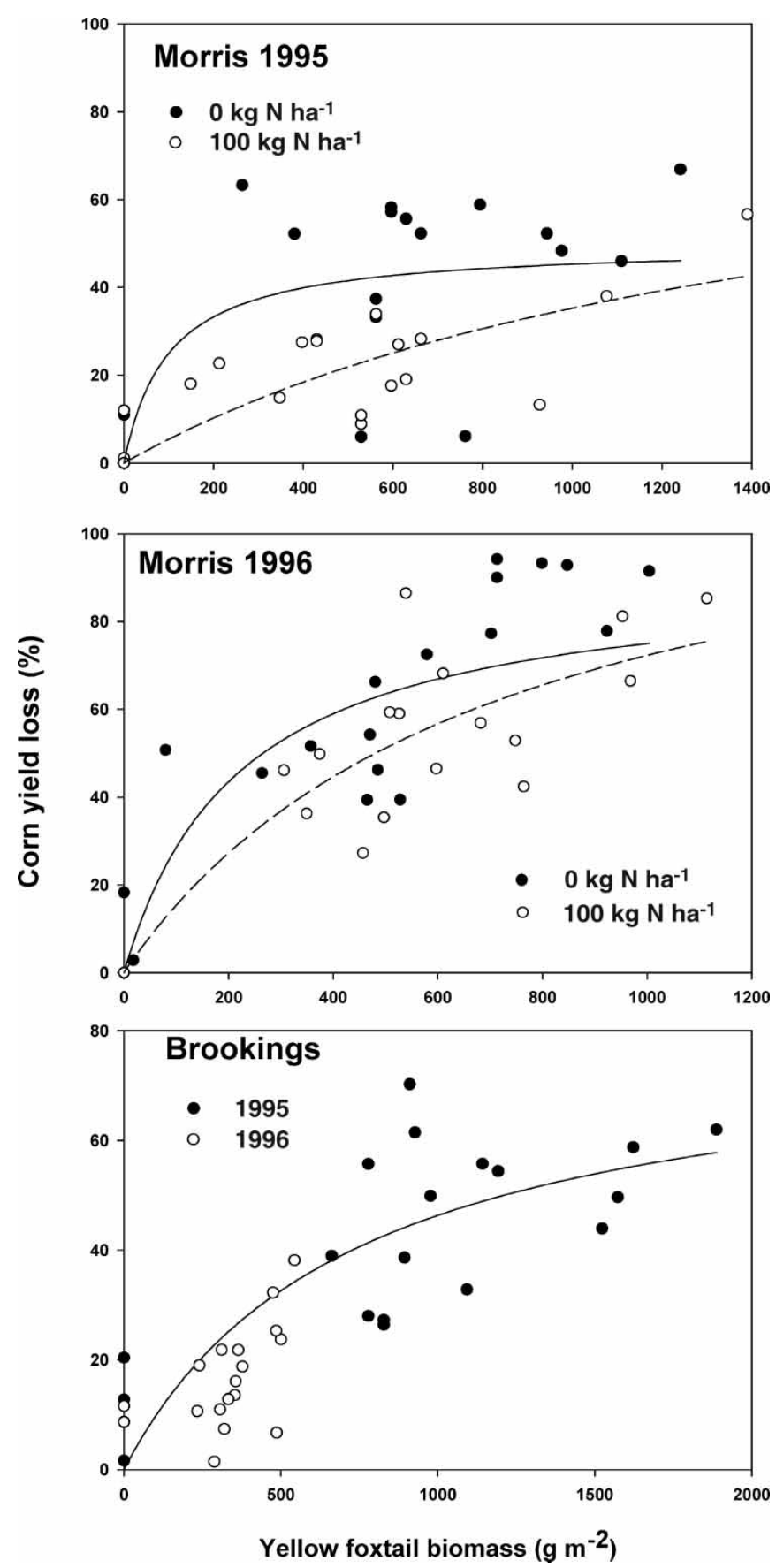

Figure 2. Corn yield loss (\%) due to yellow foxtail biomass at Morris, MN, with 0 and $100 \mathrm{~kg} \mathrm{~N} \mathrm{ha}^{-1}$ and at Brookings, SD, in 1995 and 1996. 
Table 4. Correlation coefficients ( $r$ ) of measured yellow foxtail and corn parameters in 1996 at Morris, MN, at the V-6, silking, and physiological maturity stages of corn growth with $0 \mathrm{~kg} \mathrm{~N}$ or $110 \mathrm{~kg} \mathrm{~N}$ applied per hectare

\begin{tabular}{|c|c|c|c|c|c|c|c|}
\hline \multirow{2}{*}{ Corn growth stage } & \multirow{2}{*}{$\begin{array}{c}\text { Parameter } \\
\text { measured }\end{array}$} & \multicolumn{3}{|c|}{$0 \mathrm{~kg} \mathrm{~N} \mathrm{ha}{ }^{-1}$} & \multicolumn{3}{|c|}{$110 \mathrm{~kg} \mathrm{~N} \mathrm{ha}^{-1}$} \\
\hline & & $\begin{array}{c}\text { Foxtail } \\
\text { biomass }\end{array}$ & \multicolumn{2}{|c|}{ Corn } & $\begin{array}{c}\text { Foxtail } \\
\text { biomass }\end{array}$ & \multicolumn{2}{|c|}{ Corn } \\
\hline V6 & $\begin{array}{l}\text { Foxtail density } \\
\text { Foxtail biomass } \\
\text { Corn biomass }\end{array}$ & 0.85 & $\begin{array}{l}-0.56 \\
-0.62\end{array}$ & - & 0.91 & $\begin{array}{c}-0.61 \\
\mathrm{NS}^{a}\end{array}$ & - \\
\hline $\begin{array}{c}\text { Physiological } \\
\text { maturity }\end{array}$ & $\begin{array}{l}\text { Foxtail density } \\
\text { Foxtail biomass } \\
\text { Corn biomass }\end{array}$ & 0.76 & $\begin{array}{l}-0.78 \\
-0.72\end{array}$ & $\begin{array}{r}-0.77 \\
-0.69 \\
0.99\end{array}$ & 0.76 & $\begin{array}{l}-0.77 \\
-0.81\end{array}$ & $\begin{array}{r}-0.69 \\
-0.79 \\
0.96\end{array}$ \\
\hline
\end{tabular}

${ }^{a} \mathrm{NS}$ indicates correlation between parameters is $p>0.05$. All other values are significant at $p \leq 0.05$. 
Based on WeedCast2 simulations (Archer, Eklund, and Forcella 2000), the proportion of the yellow foxtail emerged at 15 DAP was estimated to be $13.1 \%$ and $8.3 \%$ of the total emerged in 1995 and 1996, respectively. These proportions were $50 \%$ greater and $26 \%$ less than those estimated at the Morris site in 1995 and 1996, respectively. Foxtail biomass and density were correlated positively within a sampling date (Table 5). Foxtail biomass averaged across density increased from 290 to $1990 \mathrm{~g} \mathrm{~m}^{-2}$ from V-6 to physiological maturity of corn, respectively, in 1995. Foxtail biomass in 1996 averaged $100 \mathrm{~g} \mathrm{~m}^{-2}$ at V-6 to about $600 \mathrm{~g} \mathrm{~m}^{-2}$ at physiological maturity. As density increased, individual plant biomass decreased (data not shown), and these data were similar to those from Morris.

Corn biomass was correlated negatively with foxtail density and biomass in both years (Table 5 and Figure 1) and ranged from 30 to $45 \%$ less than biomass in the weed-free plots at each sampling date (data not shown). When averaged across all foxtail densities, corn biomass averaged about $720 \mathrm{~g} \mathrm{~m}^{-2}$ at silking in 1995, which was $40 \%$ less in 1996. At physiological maturity, corn biomass averaged $850 \mathrm{~g} \mathrm{~m}^{-2}$ in 1995 and about $4,300 \mathrm{~g} \mathrm{~m}^{-2}$ in 1996. The very wet conditions in 1995 hampered corn growth but benefited foxtail growth. In 1996, a slightly warmer and drier year, foxtail biomass was about $60 \%$ less at harvest compared to biomass in 1995, most likely due to interference from corn.

The average yields in weed-free treatments in 1995 and 1996 were about 12,700 and $15,000 \mathrm{~kg} \mathrm{ha}^{-1}$, respectively. The maximum yield loss based on density $\left(A_{d}\right)$ in 1995 was about $65 \%$ (Lindquist et al. 1999), whereas $A_{b}$ was $57 \%$ (Table 3 ). The $10 \%$ grain yield loss due to yellow foxtail biomass was estimated to occur at about $110 \mathrm{~g} \mathrm{~m}^{-2}$. In 1996, the maximum measured yield loss based on foxtail biomass was about $30 \%$. The incremental yield loss per $\mathrm{g}$ foxtail biomass $\mathrm{m}^{-2}\left(I_{b}\right)$ was 0.11 in 1995 and could not be estimated from the hyperbolic equation in 1996 because some plots with high amounts of foxtail biomass had very low yield losses (Figure 2). Ten percent yield loss was estimated to occur with $256 \mathrm{~g}$ foxtail biomass $\mathrm{m}^{-2}$.

\section{Morris and Brookings}

Combining data taken at silking for both sites and years indicated that total corn $\mathrm{N}$ uptake was correlated positively with corn biomass (Figure 3 ). This trend was not evident at the earlier vegetative sampling date (data not shown). It has been estimated that 60 to $75 \%$ of the total $\mathrm{N}$ taken up by a corn plant is taken up by the silking stage of growth (Martin, Leonard, and Stamp 1976; Stichler and McFarland 2001). For a yield goal of 7,500 kg $\mathrm{ha}^{-1}$, estimated plant $\mathrm{N}$ at harvest should be about $233 \mathrm{~kg} \mathrm{ha}^{-1}$ (Martin, Leonard, and Stamp 1976; Stichler and McFarland 2001). Therefore at silking, total plant $\mathrm{N}$ for a non- $\mathrm{N}$-stressed plant in this study should have been between 139 and $160 \mathrm{~kg} \mathrm{~N} \mathrm{ha}^{-1}$. It appears that almost all corn plants 
Table 5. Correlation coefficients $(r)$ of measured yellow foxtail and corn parameters in 1995 and 1996 at Brookings, SD, locations at V-6, silking, and physiological maturity of corn growth

\begin{tabular}{|c|c|c|c|c|c|c|c|}
\hline \multirow{2}{*}{ Corn growth stage } & \multirow{2}{*}{ Parameter measured } & \multicolumn{3}{|c|}{1995} & \multicolumn{3}{|c|}{1996} \\
\hline & & $\begin{array}{c}\text { Foxtail } \\
\text { biomass }\end{array}$ & \multicolumn{2}{|c|}{ Corn } & $\begin{array}{c}\text { Foxtail } \\
\text { biomass }\end{array}$ & \multicolumn{2}{|c|}{ Corn } \\
\hline \multirow[t]{2}{*}{ V6 } & Foxtail density & \multirow[t]{2}{*}{0.85} & -0.71 & - & \multirow[t]{2}{*}{0.79} & -0.41 & - \\
\hline & Foxtail biomass & & -0.72 & - & & -0.42 & - \\
\hline \multirow{2}{*}{ Silking } & Foxtail biomass & \multirow{2}{*}{0.95} & -0.73 & - & \multirow{2}{*}{0.89} & -0.39 & - \\
\hline & Corn biomass & & & - & & & - \\
\hline \multirow{3}{*}{$\begin{array}{l}\text { Physiological } \\
\text { maturity }\end{array}$} & Foxtail density & \multirow[t]{3}{*}{0.55} & -0.59 & -0.62 & \multirow[t]{3}{*}{0.62} & -0.65 & -0.69 \\
\hline & Foxtail biomass & & -0.79 & -0.76 & & -0.69 & -0.69 \\
\hline & Corn biomass & & & 0.93 & & & 0.84 \\
\hline
\end{tabular}

${ }^{a}$ Values are significant at $p \leq 0.05$ 


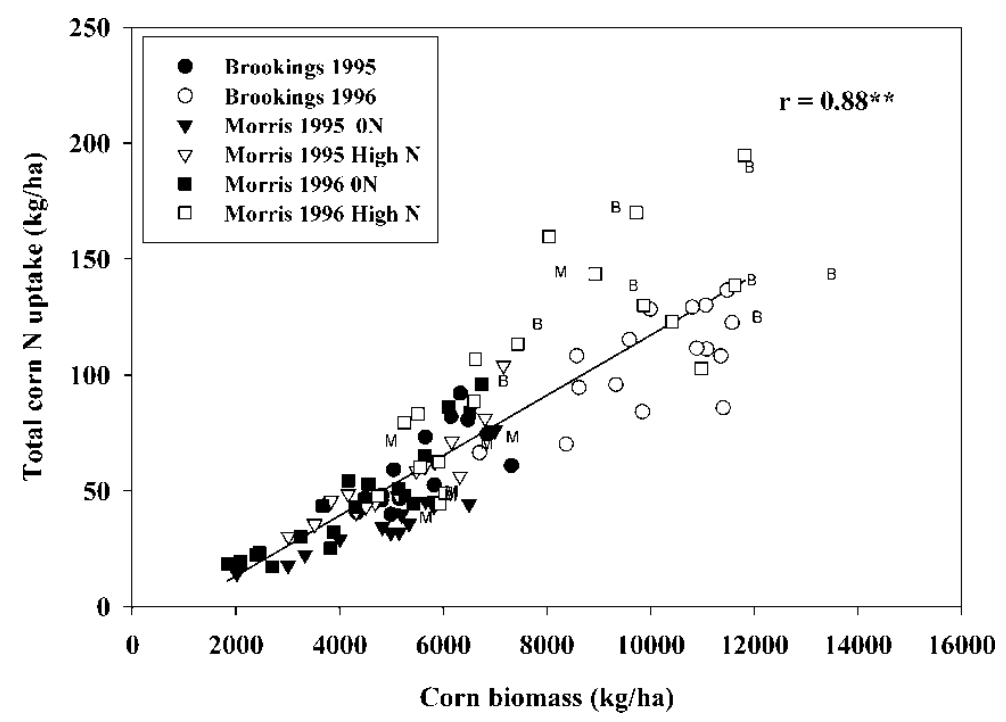

Figure 3. Amount of total nitrogen in corn biomass sampled at the silking stage of corn growth at Brookings, SD, and Morris, MN, in 1995 and 1996. All nontext symbols indicate corn samples taken from yellow foxtail-infested treatments. Letters indicate $\mathrm{N}$ uptake values of corn in weed-free treatments for either 1995 or 1996 (M = Morris location; $\mathrm{B}=$ Brookings location).

sampled were under $\mathrm{N}$ stress at silking, and yellow foxtail interference exaggerated the effect of this stress. At Morris, corn plants, even in no-weed, high-N treatments, would have been classified as $\mathrm{N}$ stressed.

The $A_{d}$ and $I_{d}$ parameters for yellow foxtail density, indicators of yield loss, combined across sites and years were correlated negatively to total season GDD ( $r=-0.95 ; p=0.05$ for both parameters) with less yield loss when GDD totals were greater than 1,340 compared with losses when GDD totals were less (data not shown). In addition, $I_{d}$ tended to be greater when the estimated proportion of early-emerging weed seedlings was high 15 DAP $(r=0.8 ; p=0.10)$. These latter results are similar, in principle, to those of Bosnic and Swanton (1997), who reported greater corn yield losses when barnyardgrass [Echinochloa crus-galli (L.) Beauv.] emerged at the $\mathrm{V} 1-\mathrm{V} 2$ stage of corn growth compared with losses when it emerged at or after V4 stage of corn growth.

Lindquist et al. (1999) reported on the stability of corn-foxtail (giant, green, and yellow) interference relationships across the midwestern United States, including Brookings and Morris. Whereas $A_{d}$ (the maximum percent corn yield loss) was stable for Brookings and Morris within a site, $I_{d}$ varied between sites and years. Economic threshold levels (based on a cost of $\$ 49.40 / \mathrm{ha}$ for management tactic, corn price of $\$ 0.10 / \mathrm{kg}$, and efficacy of management tactic of 90\%) at Morris in 1995 and 1996 were 
reported as 43 and 19 plants $\mathrm{m}^{-2}$ of row, respectively and at Brookings, 3 and 55 plants $\mathrm{m}^{-2}$ of row, respectively.

\section{CONCLUSIONS}

Data from this study indicate that yield loss because of yellow foxtail cannot be predicted easily, but the magnitudes of some common variables do aid in determining whether yield losses can be expected. Yellow foxtail density, time of yellow foxtail emergence, soil $\mathrm{N}$ status, and timing of $\mathrm{N}$ application were all factors that influenced corn yield loss, which matches results from other studies of crop-weed interference. In addition, results from this study show that weather also had a large influence on crop-weed interference. Corn growth was poor in years that accumulated few GDD after planting, and this is when weed-induced asymptotic yield loss (based on either $A_{d}$ or $A_{b}$ ) and intrinsic competitive ability (based on either $I_{d}$ or $I_{b}$ ) were highest. Interesting future research might focus on the ability to predict yield losses in real time early in the growing season based upon relative accumulations of GDD.

\section{ACKNOWLEDGMENTS}

This is South Dakota Agricultural Experiment Station publication no. 3313.

\section{REFERENCES}

Anderson, R.L. (2000) Cultural systems to aid weed management in semiarid corn (Zea mays). Weed Technology, 14: 630-634.

Archer, D.W., Eklund, J.J., and Forcella, F. (2000) WeedCast2.0. Available at www. morris.ars.usda.gov [accessed May 2002].

Banken, K.R. (2000) Influence of yellow foxtail (Setaria glauca (L.) Beauv.) on corn (Zea mays L.) growth and western corn rootworm (Diabrotica virgifera virgifera LeConte) development. MS thesis, South Dakota State University.

Barrie, A., Brooks, S.T., Prosser, J.J., and Debney, S. (1995) High productivity for ${ }^{15} \mathrm{~N}$ and ${ }^{13} \mathrm{C}$ in soil/plant research. Fertilizer Research, 42: 43-59.

Bosnic, A.C. and Swanton, C.J. (1997) Influence of barnyardgrass (Echinochloa crus-galli) time of emergence on corn (Zea mays). Weed Science, 45: 276-282.

Bridges, D.C. (1992) Crop Losses Due to Weeds in the United States, 1992; Weed Science Society of America: Champaign, Illinois.

Clay, S.A. and Scholes, K.A. (1992) Characterization of seed bank compositions and seedling emergence. Proceedings of South Dakota Academy of Science, 71: 53-65.

Cousens, R. (1985) A simple model relating yield loss to weed density. Annals of Applied Biology, 107: 239-252.

Darlington, H.T. (1951) The seventy-year period for Dr. Beal's seed viability experiment. Americal Journal of Botany, 38: 379. 
Dawson, J.H. and Bruns, V.F. (1975) Longevity of barnyardgrass, green foxtail, and yellow foxtail seeds in soil. Weed Science, 23: 437-440.

Forcella, F., Westgate, M.E., and Warnes, D.D. (1992) Effect of row width on herbicide and cultivation requirements in row crops. American Journal of Alternative Agriculture, 7: 161-167.

Forcella, F., Wilson, R.G., Dekker, J., Kremer, R.J., Cardina, J., Anderson, R.L., Alm, D., Renner, K.A., Harvey, R.G., Clay, S., and Buhler, D.D. (1997) Weed seed bank emergence across the corn belt. Weed Science, 45: 67-76.

Hatton, P.J., Cole, D.J., and Edwards, R. (1996) Influence of plant age on glutathione levels and glutathione transferases involved in herbicide detoxification in corn (Zea mays L.) and giant foxtail (Setaria faberi Herrm.). Pesticide Biochemistry and Physiology, 54: 199-209.

Lindquist, J.L., Mortenson, D.A., Westra, P., Lambert, W.J., Bauman, T.T., Fausey, J.C., Kells, J.J., Langton, S.J., Harvey, R.G., Bussler, B.H., Banken, K., Clay, S., and Forcella, F. (1999) Stability of corn (Zea mays)-foxtail (Setaria spp.) interference relationships. Weed Science, 47: 195-200.

Martin, J.H., Leonard, W.H., and Stamp, D.L. (1976) Indian corn or maize. In Principles of Field Crop Production, 3rd ed.; Macmillian Publishing: New York, NY, 323-382.

Mulvaney, R.L. (1996) Nitrogen-inorganic forms. In Methods of Soil Analysis; Part 3: Chemical Methods; Sparks, D.L. (ed.); Soil Science Society of America and American Society of Agronomy: Madison, Wisconsin, 1123-1184.

Nieto, J. and Staniforth, D.W. (1961) Corn-foxtail competition under various production conditions. Agronomy Journal, 53: 1-5.

Rominger, J.M. (1962) Taxonomy of Setaria (Gramineae) in North America. University of Illinois Press: Urbana, Illinois, Illinois Biological Monographs: No. $29,1-2$.

SAS Institute. (1989) SAS user's guide: statistics. Version 6th ed.; SAS Institute: Cary, North Carolina.

Schoner, C.A., Norris, R.F., and Chilcote, W. (1978) Yellow foxtail (Setaria lutescens) biotype studies: Growth and morphological characteristics. Weed Science, 26: 632-636.

Stevens, O.A. (1932) The number and weight of seeds produced by weeds. American Journal of Botany, 19: 784-794.

Stichler, C. and McFarland, M. (2001) Crop Nutrient Needs in South and Southwest Texas. Texas Agricultural Extension Service, Texas A\&M University: College Station, Texas; B-6053.

Tollenaar, M., Nissanka, S.P., Aguilera, A., Weise, S.F., and Swanton, C.J. (1994) Effect of weed interference and soil nitrogen on four maize hybrids. Agronomy Journal, 86: 596-601.

Wang, R.L. and Dekker, J. (1995) Weedy adaptation in Setaria spp. III: Variation in herbicide resistance in Setaria spp. Pesticide Biochemistry and Physiology, 51: 99-116. 